\title{
Application of Remediation Technique for the Quaternary Aquifer in El-Sheikh Zowied - Rafah Area, North Sinai, Egypt
}

\author{
Ezz El-Din El-Tablawi*
}

Hydrology Department, Desert Research Center, Cairo P.O.B. 11753 Egypt

\section{A R T I C L E I N F O}

Article history:

Received 30 May 2012

Accepted 11 June 2012

Keywords:

Quaternary aquifer;

Hydrodynamic isolation system;

Groundwater;

Remediation technique.

\begin{abstract}
A B S T R A C T
An encroachment of sea water due to over pumping in El-Sheikh Zowied-Rafah area leads to increase the zones of salts plume in the Quaternary aquifer. The present study aims to construct a model of hydrodynamic isolation system for groundwater cleanup to a specified level and to reach the balance. The obtained results give rise to the Retardation factor of the Quaternary aquifer in the studied area (2.51). The study indicates that the stored volumes of water in pores vary from $0.1 \times 10^{6} \mathrm{~m}^{3}$ to $6 \times 10^{6} \mathrm{~m}^{3}$ for each cell of model grid in the studied area. The number of pore volumes ranges from one to six pore volumes for each cell of model grid. The longest time for displacement of single pore volume reaches 600 day. The time for cleanup of the groundwater in the aquifer to a specified level, varies from less than 600 day to about 3800 day. A numbers of Capture zones are detected in the studied area as a result of hydrodynamic isolation system model.
\end{abstract}

\section{Introduction}

Groundwater contamination has become an increasingly prevalent problem. Therefore, the development of the effective and efficient remediation techniques is an argent target. Hydrodynamic barriers around a contaminant source and plume can be accomplished primarily in one of two ways. Groundwater cut off-walls (slurry walls) can be physically installed around the zone of contamination. The walls are typically composed of either a soil-bentonite mixture or concrete of sufficiently low hydraulic conductivity ${ }^{[1]}$. This prevents the groundwater flow through the contaminant zone and transporting it down gradient. A complete sealing of the contaminant zone using this method is typically very costly. Hydrodynamic controls can be used to isolate the zone of contaminated groundwater by modifying the local flow regime through the strategic placement of pumping and injection wells. This remediation technique is commonly referred to as hydrodynamic isolation. The present paper deals with the application of mathematical model in order to remediate the groundwater aquifer in the studied area. Three constructed models are applied including; hydraulic flow model, salts transport model and hydrodynamic salts dispersivity model with complete interaction between them.

\footnotetext{
* Corresponding author.

E-mail address: Ezz1960@hotmail.com
}

El-Sheikh Zowied-Rafah area lies at northeast of Sinai Peninsula (Fig. 1) occupying about $176 \mathrm{~km}^{2}$. It is subjected to over pumping from the salts source of water resource (groundwater) in order to provide the demand for human and agricultural activities.

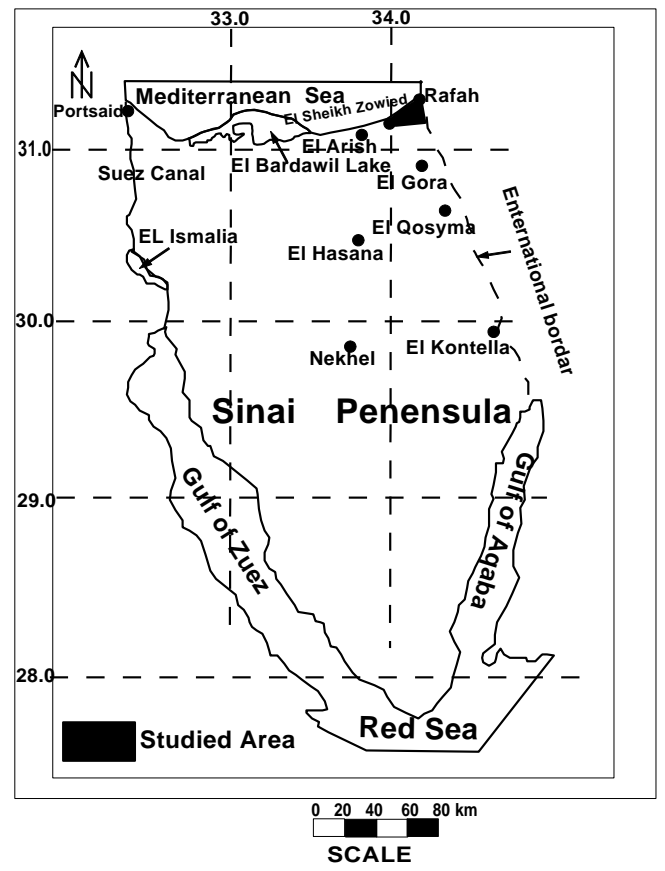

Fig. 1: Location map of the studied area (modified after ${ }^{[2]}$ ). 


\section{HYDROGEOLIGICAL BACKGROUND}

The Quaternary aquifer in the studied area represents a complex system of groundwater consisted of three water bearing rock units. They are defined as shown in Fig. 2. They are connected hydraulically and forming one hydrogeolgic aquifer system.
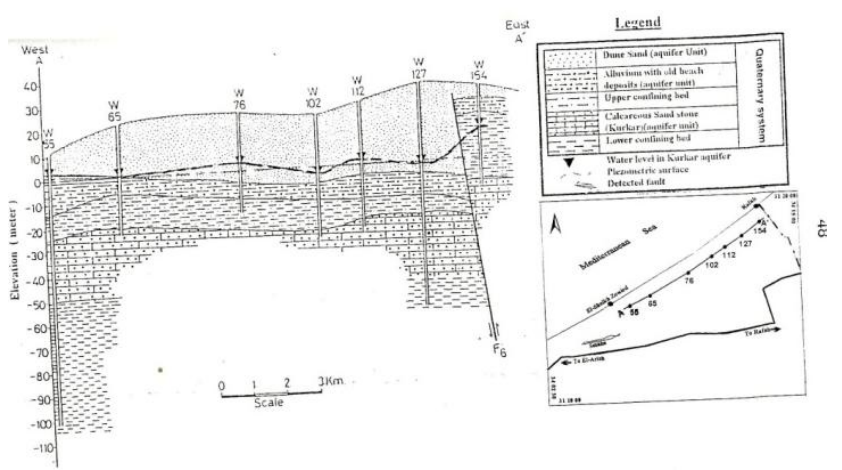

Fig. 2: Hydrogeological cross section A-A', El Sheikh ZowiedRafah, North Sinai, Egypt (After ${ }^{[3]}$ ).

1-Sand dune coastal aquifer (a seasonal aquifer). It extends parallel to the coast and recharged directly from the local rainfall precipitation. The groundwater in the aquifer exists under unconfined water table conditions with saturated thickness ranges from less than one meter to about $8 \mathrm{~m}$.

2-Alluvial aquifer; it extends along the coastal line south of the sand dune aquifer and inland for about $7 \mathrm{~km}$ away. The groundwater in the aquifer exists under unconfined conditions with saturated thickness reaches about $30 \mathrm{~m}$. The aquifer disappears south ward.

3-Calcareous sandstone aquifer (Kurkar aquifer); it is the main groundwater aquifer in the studied area. It lies south of the alluvial aquifer under the semi confined conditions to confined conditions with saturated thickness varies from 15 to $40 \mathrm{~m}$. The saturated thickness decreases due north and south.

The groundwater flows generally from South to North in the Quaternary aquifer and towards the Mediterranean sea (Fig. 3). The hydrogeological boundary conditions were considered ${ }^{[2]}$ as follows (Fig. 4):

1- Impermeable fault in the western direction.

2- Permeable rechargeable fault in the southern direction.

3- Constant head in the northern direction (Mediterranean Sea).

4- Changing in the head pressure in the north eastern and eastern direction at the international boarder.

The water salinity of the Quaternary aquifer ranges from less than $1 \mathrm{~kg} / \mathrm{m}^{3}$ to about $5 \mathrm{~kg} / \mathrm{m}^{3}{ }^{[4]}$. Fig. 5 represents the groundwater-sea water interface in the studied area [5]

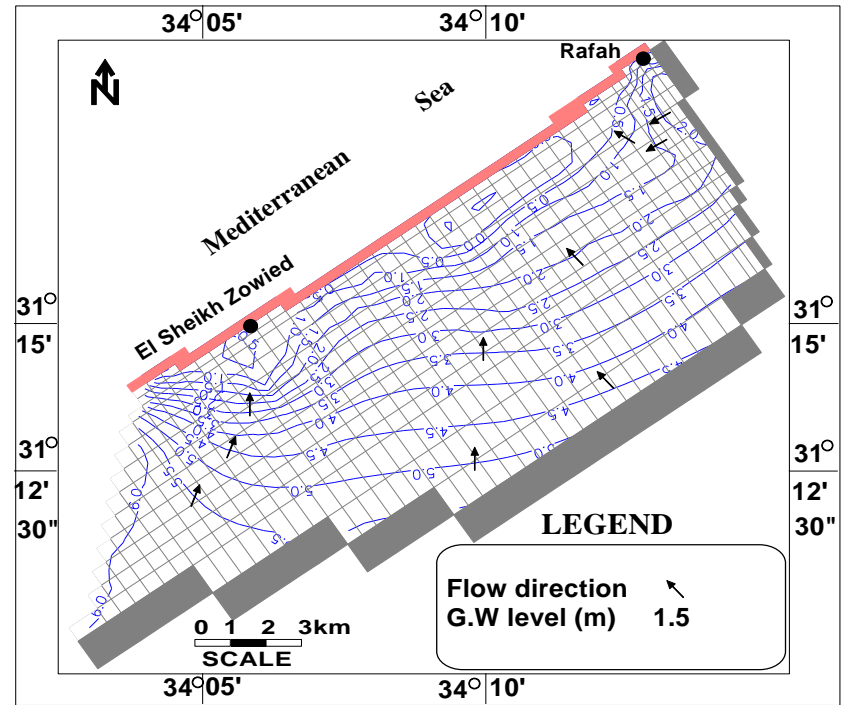

Fig. 3: Groundwater level contour map, El Sheikh Zowied - Rafah Area, North Sinai, Egypt.

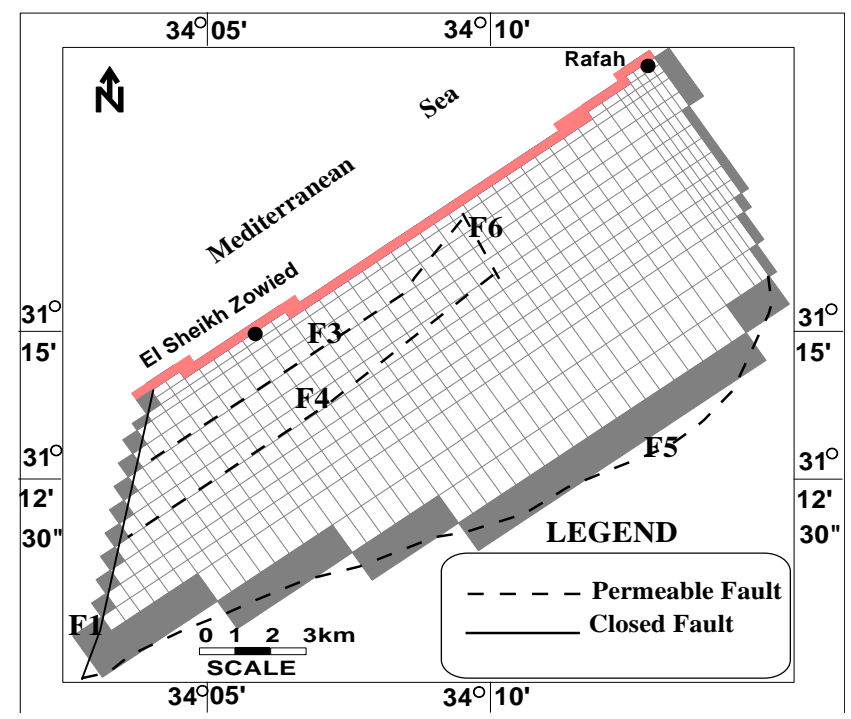

Fig. 4: Boundary conditions, El Sheikh Zowied - Rafah Area, North Sinai, Egypt (After ${ }^{[6]}$ ).

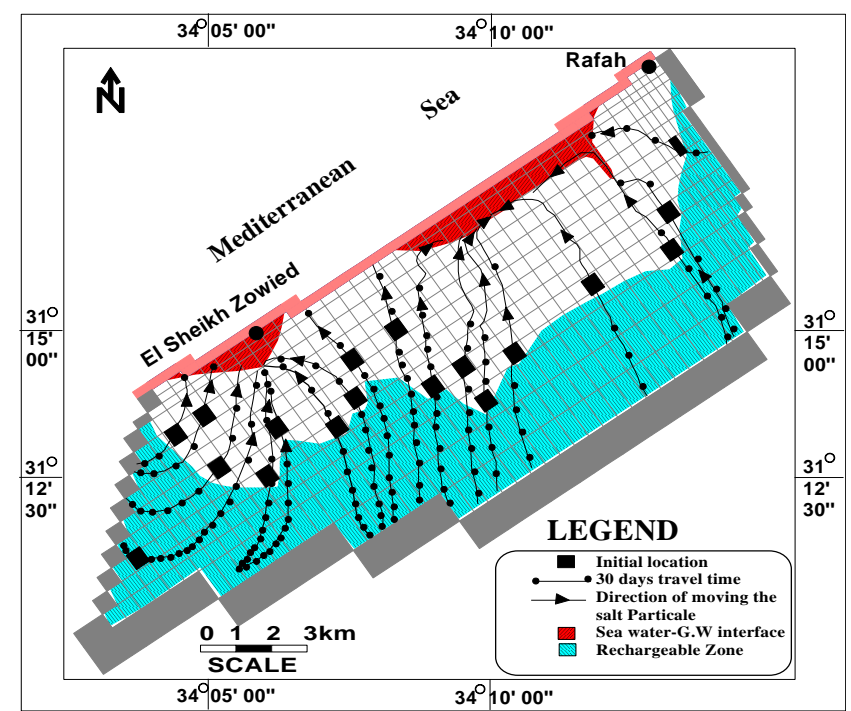

Fig. 5: Delineation Sea water-Groundwater interface and Travel time of dissolved salt particles in different locations of the complex water bearing formations, El Sheikh Zowied - Rafah Area, North Sinai, Egypt (After ${ }^{[5]}$ ). 


\section{MODELS DESCREPTION}

Detailed description of the applied models in the previous studies are presented as follows:

1-Hydraulic flow model. It was constructed on an area of about $176 \mathrm{~km}^{2}{ }^{[2]}$ for the complex of Quaternary water bearing formations. The direct recharge to the groundwater from rainfall precipitation (ranges from $200-300 \mathrm{~mm} /$ year) is estimated as 19.13 million cubic meter per year. The groundwater is pumped out from 247 wells tapping the Quaternary aquifer and estimated about 23.97 million cubic meter per year. The model was calibrated, where the values of horizontal hydraulic conductivity varies from less than $20 \mathrm{~m} /$ day in the north and northeast directions to more than $50 \mathrm{~m} /$ day in the south and southeast directions of the studied area. The result of the hydraulic flow model indicates that the studied area is subjected to over pumping along the coastal line and inland, from about $3 \mathrm{~km}$ at El Sheikh Zowied town to about $6 \mathrm{~km}$ near Rafah town. The drop of groundwater levels leads to sea water encroachment in the studied area.

2-Salts transport model ${ }^{[4]}$. It is constructed according to different parameter of advection, dispersion and diffusion. The longitudinal dispersivity is estimated as $76.8 \mathrm{~m}$, while the effective molecular diffusion is calculated as $6 \times 10^{-5} \mathrm{~m}^{2} /$ day. The model is calibrated, where the values of effective porosity of the complex water bearing formation were defined. They varied from more than 0.25 in the southern direction to less than 0.15 in the northern direction. The results of the model indicate an increasing of dissolved salts reaching more than $1 \mathrm{~kg} / \mathrm{m}^{3}$ for ten years prediction.

3-Hydrodynamic salts dispersivity model ${ }^{[5]}$. The model depends on the salts transport model. It aims to define the areas of advection, dispersion and diffusion. The result of such model indicates that the retarded velocity of the Quaternary aquifer varies from less than $0.01 \mathrm{~m} /$ day to about $10 \mathrm{~m} /$ day. The study is referred to the mechanical dispersion coefficient that ranges from about less than $5 \mathrm{~m}^{2} /$ day to about more than $600 \mathrm{~m}^{2} /$ day. Different variations of the hydrodynamic salts dispersivities are investigated. The values of Peclet number ranges from 0.4 to more than 40 . The travel times of dissolved salt particles from rechargeable areas to dischargeable areas are changed from about three to twenty months.

\section{THE CURRENT MODEL}

The current model is the hydrodynamic isolation system model.

It is applied in the present study depending on the application of the previous three models; hydraulic flow model ${ }^{[2]}$, Salts transport model ${ }^{[4]}$ and hydrodynamic salts dispersivity model ${ }^{[5]}$. The current model is applied using the interaction of three programs; three dimensional hydraulic MLODFLOW, three dimensional contaminant transport model MT3D and three dimensional particle tracking program PM-PATH. Such programs are adopted by ${ }^{[7]}$. The current model is represented by network of irregular and regular cells of the same dimensions in the hydraulic flow model ${ }^{[2]}$. Such model cover the area of about 175.625 square kilometer and discrete to 659 cells. The grid Peclet numbers $(\mathrm{Pe})$ of regular cells are 3.2 and 6.5 , While the grid Peclet number $(\mathrm{Pe})$ for irregular cells are 4.8, 8.1 and 9.8. The average grid Peclet number $(\mathrm{Pe})$ of the current model is 6.5. This Peclet number is acceptable to avoid numerical dispersion. Acceptable solution may be obtained with grid Pe as high as $10^{[8]}$. The current model was run depending on the hydrological and hydrochemical data as discussed in the previous models. Twelve stress periods have been taken with 30 days for each in transient simulation. The model is running daily with 30 days time step and one transport step size.

\section{CLEANUP TIME}

The time required to achieve the cleanup standard of groundwater under various remedial alternatives is obtained by estimation of time required for one pore volume of clean water to flush through the area and multiplying this by the required number of pore volumes [9]. The time required for displacement of one pore volume through the studied area was estimated through the three-dimensional particle tracking program PMPATH, numerous particles were initiated within and along the upstream of the studied area the longest calculated time was taken as the time required of displacement of one pore volume. The pore volume is the volume of pore space. In the studied area, the longest calculated time is calculated as 22 months (660 day) ${ }^{[5]}$. The number of pore volume (Npv) required to reduce the initial dissolved concentration (Ci) and to cleanup standard or target concentration (Cs) is given by the following equation ${ }^{[9]}$ :

$\mathrm{Npv}=-\mathrm{R} \ln \frac{\mathrm{Cs}}{\mathrm{Ci}}$

The cleanup standard or target concentration (Cs) is assumed to be $0.5 \mathrm{Kg} / \mathrm{m}^{3}$, while the initial dissolved concentration $(\mathrm{Ci})$ is adopted by El-Tablawi ${ }^{[4]}$, see Fig. 6. The dissolved salts concentration of the Quaternary aquifer varies from about $5 \mathrm{~kg} / \mathrm{m}^{3}$ in the southern area to less than $1 \mathrm{Kg} / \mathrm{m}^{3}$ in the northern area of the studied area. The retardation factor $(\mathrm{R})$ includes all of the interactions between the chemical species and the solid surfaces of porous media. These interactions tend to retard the migration of chemical relative to the water and delay its arrival down gradient ${ }^{[10]}$. 
The locations of the reactive and nonreactive salts plume relative to the source area are compared and the retardation factor is calculated as follows ${ }^{\text {11] }}$

$R=$ Distance from source of nonreactive plume

$R=$ Distance from source of reactive plume

Retardation can be also estimated using temporal data as follows:

$\mathbf{R}=$ Time for reactive chemical to reach a given point

Time for nonreactive chemical to reach a given point

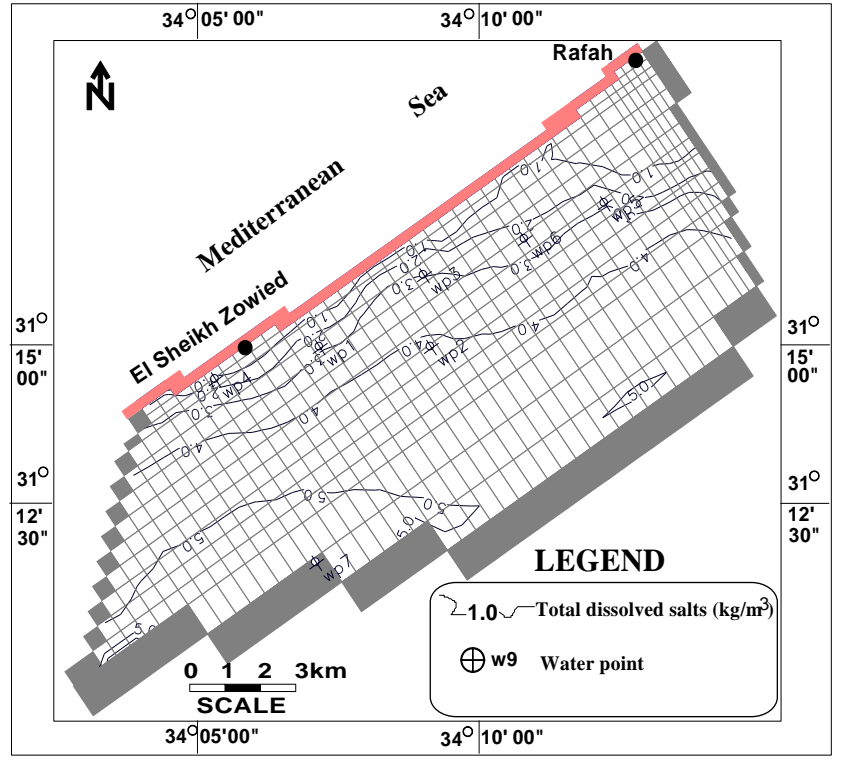

Fig. 6: Initial concentration of dissolved salts $\left(\mathrm{kg} / \mathrm{m}^{3}\right)$ for the quaternary aquifer in El Sheikh Zowied - Rafah Area, North Sinai, Egypt (After $\left.{ }^{[4]}\right)$.

According to Zheng and Bennett ${ }^{[9]}$, the retardation factor can be interpreted as a ratio of the breakthrough time at outflow face for sorbing tracer, to that for a nonsorbing tracer (Fig. 7 (A)). In the field situation, the retardation factor can be interpreted as the observed distance traveled by the front of nonsorbing solute plume to that of sorbing solute plume (Fig. 7 (B)). From the above discussion, the retardation factor in the studied area is estimated from the hydrodynamic salt dispervity map (Fig. 8) as follows:

1. Retardation factor at El-Sheikh Zowied:

$R=\frac{\mathrm{HL}}{\mathrm{HK}}=\frac{5750 \mathrm{~m}}{3500 \mathrm{~m}}=1.64$

2. Retardation factor at Rafah:

$R=\frac{A C}{A B}=\frac{7500 m}{3500 ~ m}=2.14$

3. Retardation factor at the area between ElSkeikh Zowied and Rafah:

$R=\frac{E G}{E F}=\frac{7500 ~}{2000 ~} \mathbf{~ m}=3.75$

The average retardation factor in the studied area reaches 2.51. In the contaminant transport, one of the advection and dispersion is mostly common than the other depending on the retardation factor.
If the retardation factor is equal to 1 , then the advection is mostly common. While, if the retardation factor exceeds 1 , the dispersion is mostly common. In the current model the dispersion is mostly common in the studied area.

The distances HL, AC and EG represents the distances traveled by the front of nonsorbing salts plume, while the distances $\mathrm{HK}, \mathrm{AB}$ and $\mathrm{EF}$ represents the distances traveled by sorbing salts plume. The mechanism of chemical processes that occur in the studied Quaternary aquifer reflect that salts plume are removed from the water and immobilized in or on the solid matrix of the porous medium by electrostatic forces, which referred to sorption process. The opposite process occurs, where the salts particles are detached from the solid matrix and reenter the dissolved phase which is referred to desorption. Sorption includes adsorption and absorption processes. Adsorption refers to adherence of chemical species primarily on the surface of the porous matrix, while absorption refers to more or less uniform penetration of chemical species into solid grain.

The volume of pore space reflect the volume of water in pore space and it can be calculated from the following equation ${ }^{[9]}$

Volume of water $=\boldsymbol{\theta} \times \mathrm{A} \times \mathrm{L}$

Where:

$\boldsymbol{\theta}$ : Effective porosity

A: Cross-sectional area

L: Aquifer thickness

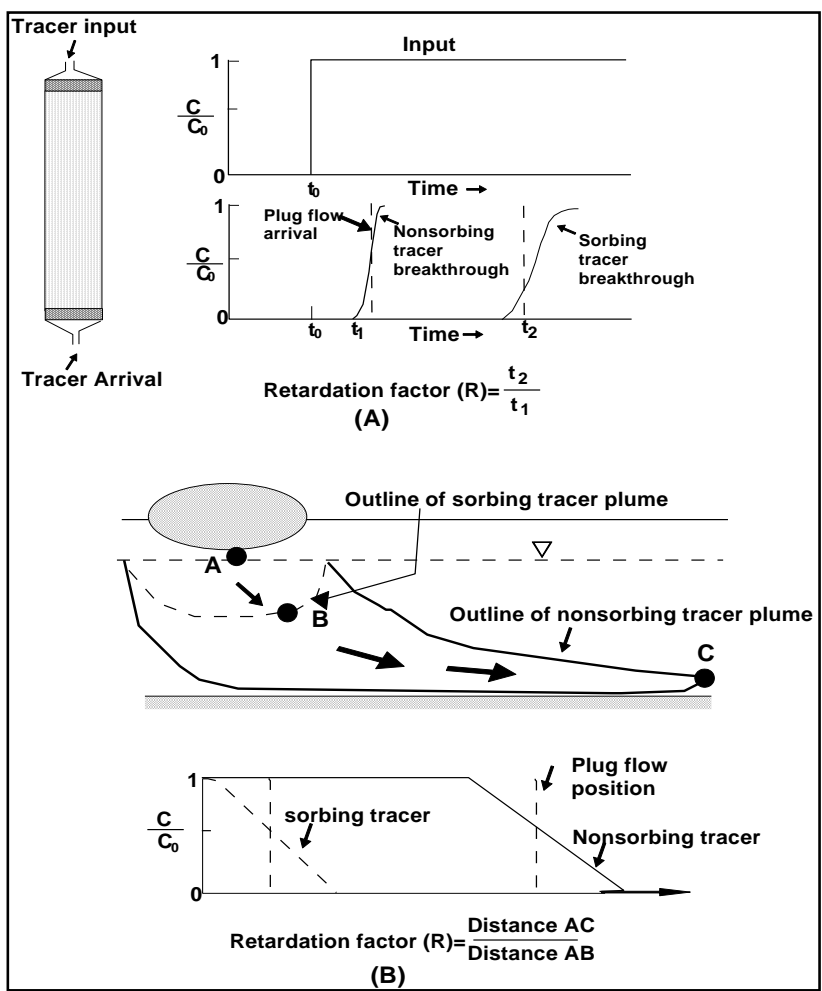

Fig. 7: Schematic illustration of the retardation concept: (A) the ideal laboratory case and (B) a hypothetical field case (modified from ${ }^{[12]}$ ). 


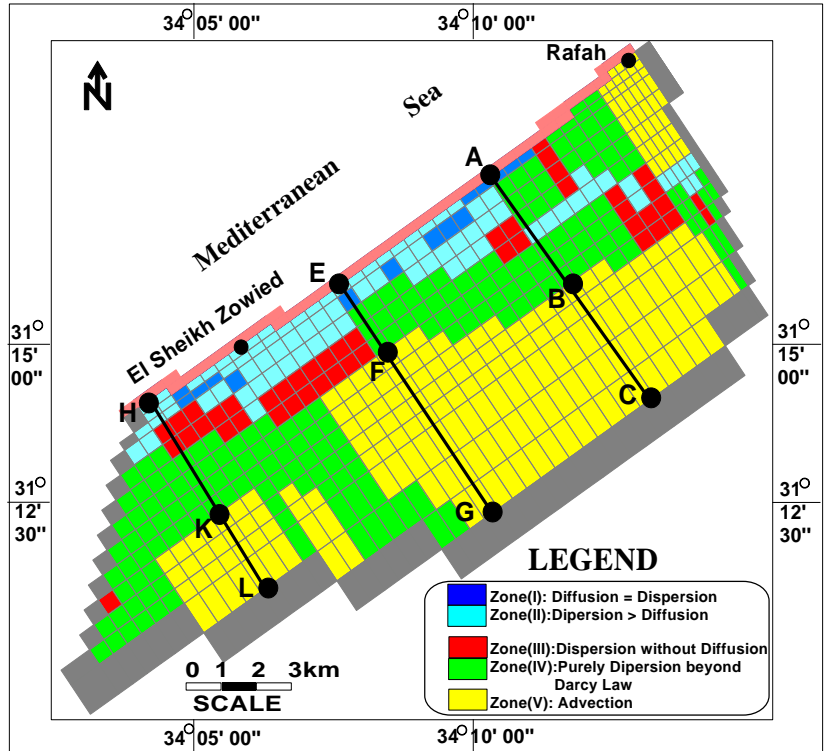

Fig. 8: The hydrodynamic salt dispersivities and advective zones in the complex water bearing formations, El Sheikh Zowied Rafah Area, North Sinai, Egypt (After ${ }^{[5]}$ ).

The effective porosity is calculated from salts transport model ${ }^{[4]}$, while the thickness of the Quaternary aquifer is calculated from the hydraulic flow model ${ }^{[2]}$. Fig 9 represents the volume of water in pores for the Quaternary aquifer in the studied area. It varies from 0.1 x $10^{6} \mathrm{~m}^{3}$ to $6 \times 10^{6} \mathrm{~m}^{3}$ for each cell of model grid in the studied area. The higher volume lies in the southern areas, while the lower one is located in the northern areas. The calculated total volume of water in pores in the studied area is 1500 million cubic meter. The current model used three - dimensional particle tracking PMPATH in conjunction with three - dimensional flow simulation MODFLOW to calculate the time required for single pore volume and to verify full capture of salts plume in groundwater by remedial installations.

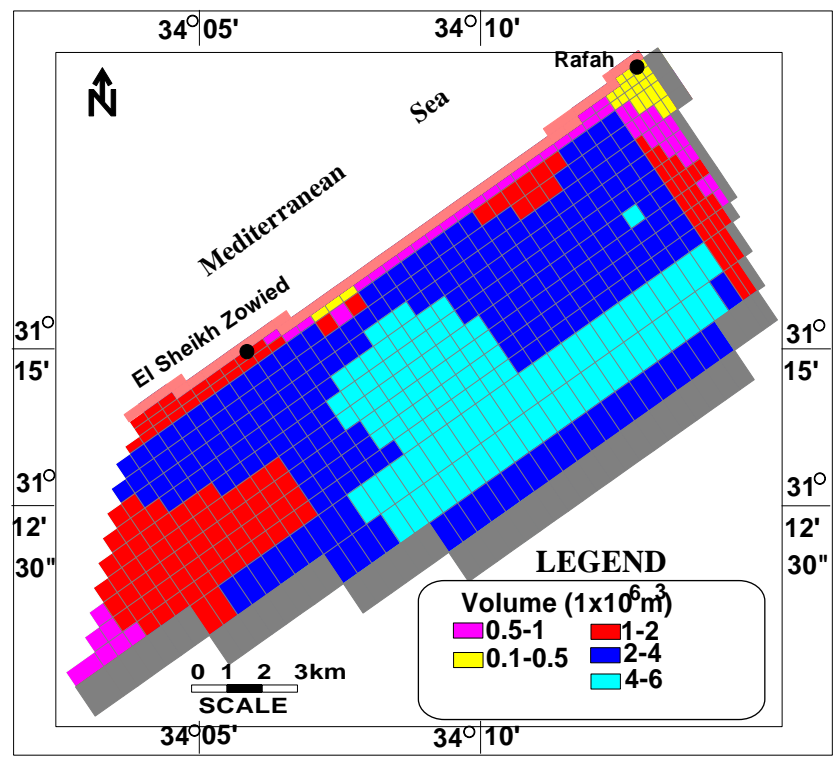

Fig. 9: Volume of water in pore space for the quaternary aquifer in El Sheikh Zowied - Rafah Area, North Sinai, Egypt.
Fig. 10 represents the number of pore volume (Npv) required for groundwater cleanup to specified level in the studied area. It varies from one pore volume in the northern area to six pore volumes for each cell of model grid in the southern area. The efficiency of groundwater in the studied area varies from very low with pore volume ranges from 1 to 2 to very high, with pore volume ranges from 5 to 6 . The full replacement of single pore volume in all parts of the studied Quaternary aquifer would require 660 days. Fig. 11 represents the groundwater cleanup time of the Quaternary aquifer in the studied area. It varies from less than 600 days in the northern area to about 3810 days in the southern area. From the above results, it can be concluded that, the remedial technique such as hydrodynamic isolation system for groundwater cleanup needs more time in the southern and middle areas than in the northern area.

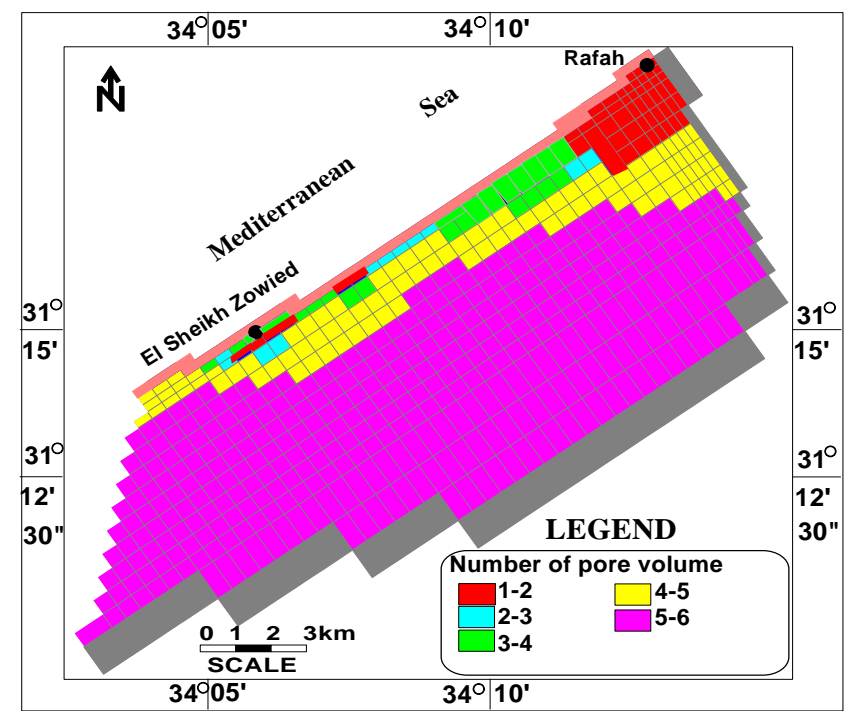

Fig. 10: Number of pore volumes required for ground water cleanup to specified level in the quaternary aquifer in El Sheikh Zowied - Rafah Area, North Sinai, Egypt.

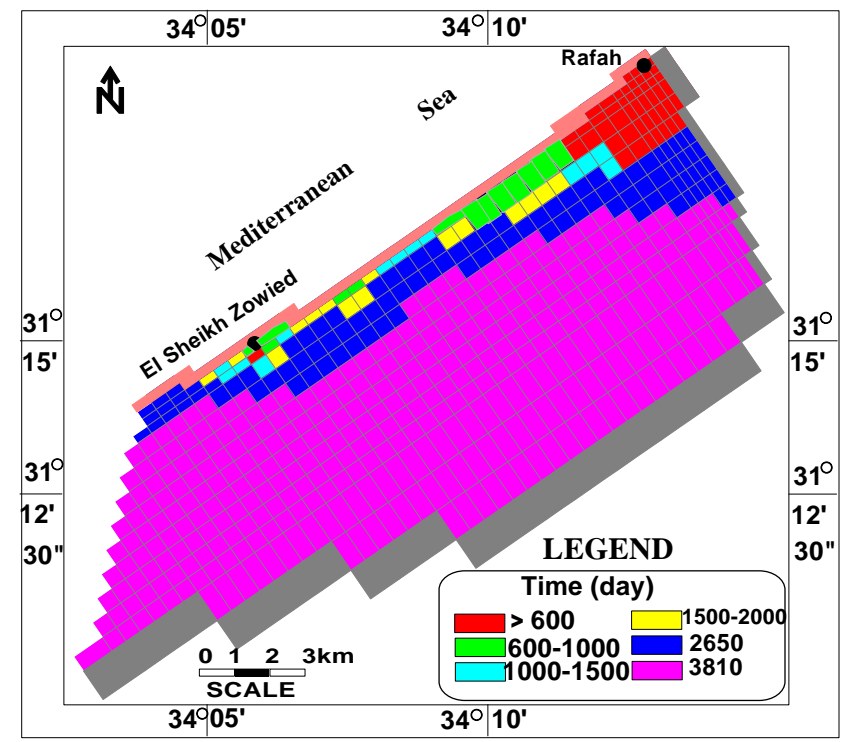

Fig. 11: Groundwater cleanup time for the quaternary aquifer in El Sheikh Zowied - Rafah Area, North Sinai, Egypt. 


\section{HYDRODYNAMIC ISOLATION SYSTEM}

Hydrodynamic isolation system varies in complexity and effectiveness. The simplest system involves a single pumping well located at either the leading edge or centroid of the salt contaminate plume. Isolation systems grow in complexity as more pumping and injection wells are employed in variety of configurations to maximize the systems effectiveness. The objective of the hydrodynamic isolation technique is to modify the groundwater flow pattern to contain contaminant plume within the capture zone of the wells. The capture zone of a well or system of wells is defined as the area contributing flow to the well. Isolation wells are useful, where they effectively prevent any further advection of contaminant down gradient ${ }^{[1]}$. Fig. 12 represents the schematic illustration of double cell hydraulic isolation system. The technique represents two injection wells located in the upstream side and two pumping wells located in the downstream side. The groundwater is pumped to the treatment station to remove the salts and reproduce pure water to be injected in the injection wells. The capture zone of a well depends on the pumping rate and aquifer conditions. However, by using more wells, the well spacing becomes an important parameter as well as pumping rate. The greater the pumping rate is the larger the capture zone, and the closer the wells are placed, the better the chance of complete plume capture. Satkin and Bedient ${ }^{[13]}$ investigate various pumping and injection well patterns to remediate contaminant plume (Fig. 13). The key hydrogeologic variables that control the rate of cleanup are; well locations, pumping rates, transmissivity, dispersivity and hydraulic gradient. The three spot, doublet and double cell well patterns are effective under low hydraulic gradient conditions. Three spot patterns showed best performance under high hydraulic gradient. Cleanup time was found to be inversely related to the pumping rate. Injected water directly into an aquifer system by means of wells is similar to normal producing well. Injected water must be of high standard. Suspended materials should less than 1 p.p.m. ${ }^{[14]}$. The high cost of injection well and water treatment usually restrict this form of recharge to particular project such as the creation of sea water barriers. The injected water has been very successful in controlling the sea water encroachment into coastal aquifer.

The average cost per mega liter $\left(1000 \mathrm{~m}^{3}\right)$ of water artificially recharged, including interest, redemption and operating costs of \$U.S 4.00 per mega liter $\left(1000 \mathrm{~m}^{3}\right)^{[14]}$. Accordingly, area of one kilometer needs $4000 \mathrm{~m}^{3}$ / day of injected water for groundwater cleanup. Then one kilometer costs \$U.S 5760 / year for injected water of about $1.5 \times 10^{6} \mathrm{~m}^{3}$. The treatment station and well drilling costs are not included.

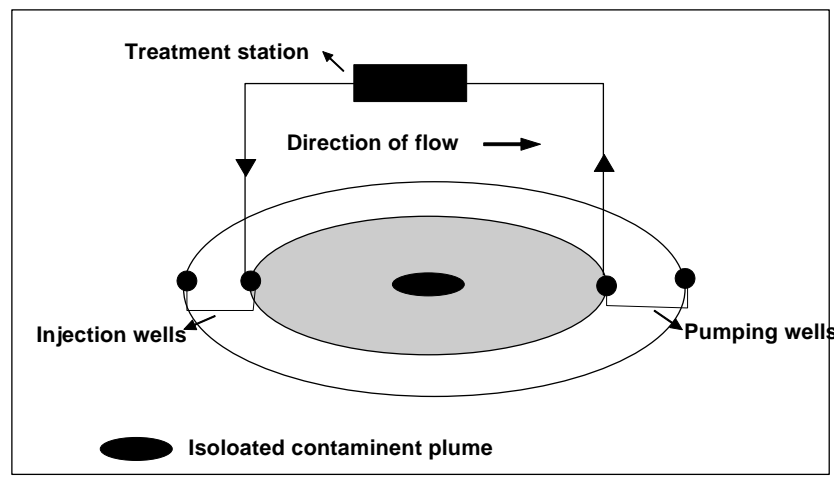

Fig. 12: Schematic illustration of double-cell hydraulic isolation system.

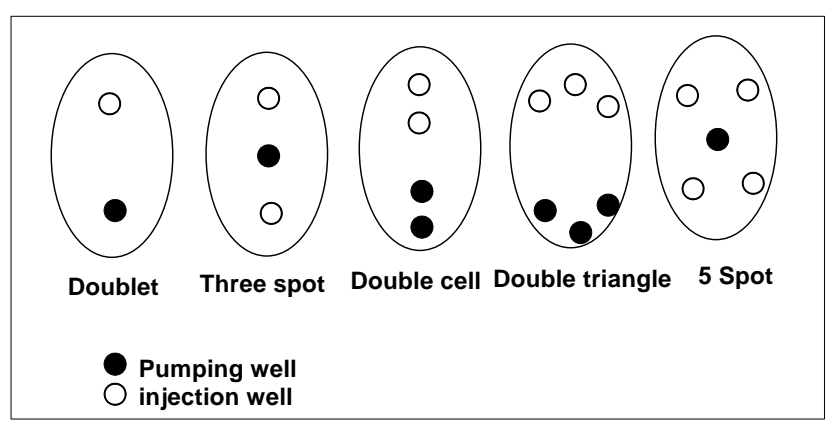

Fig. 13: Different pumping and injection well patterns used in the hydrodynamic isolation system (After ${ }^{[13]}$ ).

Hydrodynamic isolation system is modeled for the Quaternary aquifer in the studied area. The transmissivity in the studied aquifer varies from more than $2600 \mathrm{~m}^{2} /$ day in the southern parts to less than $1000 \mathrm{~m}^{2} /$ day in the northern parts ${ }^{[2]}$. While the hydraulic gradient varies from about $3.1 \times 10^{-4}$ in the southward to about $6.9 \times 10^{-4}$ northward ${ }^{[3]}$. The pumping rates from the dischargeable well vary form about $200 \mathrm{~m}^{3} /$ day to about $2000 \mathrm{~m}^{3} /$ day in the studied area ${ }^{[2]}$. Different well patterns as mentioned are applied. Two scenarios are concerned in the current model.

The first scenario: Two injection wells with $5000 \mathrm{~m}^{3} /$ day of injection rate for each well at El-Sheikh Zowied town, one injection well at Rafah with injection rate $2000 \mathrm{~m}^{3} /$ day, one injection well in the middle area south to Rafah with injection rate $2000 \mathrm{~m}^{3} /$ day and one injection well in the southern area with injection rate $6000 \mathrm{~m}^{3} /$ day are suggested. Pure water is injected for each well with constant concentration $0.050 \mathrm{~kg} / \mathrm{m}^{3}$. The model was running daily with 12 stress period of 30 day per each and 30 days time step with one transport step size for each stress period. The model was running in the transient time for 15 years. All pumping wells in the studied area were operated regularly during the simulation. The result of model simulation detects four capture zones in the studied area. One capture zone at El-Skeikh zowied, two capture zones at Rafah and one capture zone in the southern area (Fig. 14). Breakthrough curves and groundwater plots are adopted at each capture zone (Fig. 15). Breakthrough curve is the concentration-time curve. Also it can be a concentration- 
distance curve in other job. It reflects the effect of physical and chemical processes on the salts transport (Advection, diffusion, dispersion, sorption, desorption, adsorption and absorption). The concentration-time curve for model cells demonstrates the simulated changes concentration over time clearly. From such curves and plots, one can deduce the following:

At capture zone (1) (El-Skeikh Zowied area), the result of simulation indicates an expected decrease in the concentration of salts plume from $3.870 \mathrm{~kg} / \mathrm{m}^{3}$ to 1.8 $\mathrm{kg} / \mathrm{m}^{3}$ associated with increase in water level up to $2.87 \mathrm{~m}$. The groundwater cleanup time will be six years of injection, where desorption process took place. The remaining salts plume (residual) represents $47 \%$ of the actual concentration.

At capture zone (2) (the southern area), the result of simulation refers to an expected decrease in the concentration of salts plume from $4.900 \mathrm{~kg} / \mathrm{m}^{3}$ to 4.100 $\mathrm{kg} / \mathrm{m}^{3}$ associated with increase in water level up to one meter. The groundwater cleanup time will be nine years of injection, where desorption took place. The remaining salts plume (residual) represents $84 \%$ of the actual concentration.

At capture zone (3) (the middle area at Rafah), the simulation result indicates an expected decrease in the concentration of salts plume from $3.400 \mathrm{~kg} / \mathrm{m}^{3}$ to 1.790 $\mathrm{kg} / \mathrm{m}^{3}$ associated with increase in water level up to $1.25 \mathrm{~m}$. The groundwater cleanup time will be eight years of injection, where desorption process took place. The remaining salts plume (residual) will be 53\% from the actual concentration.

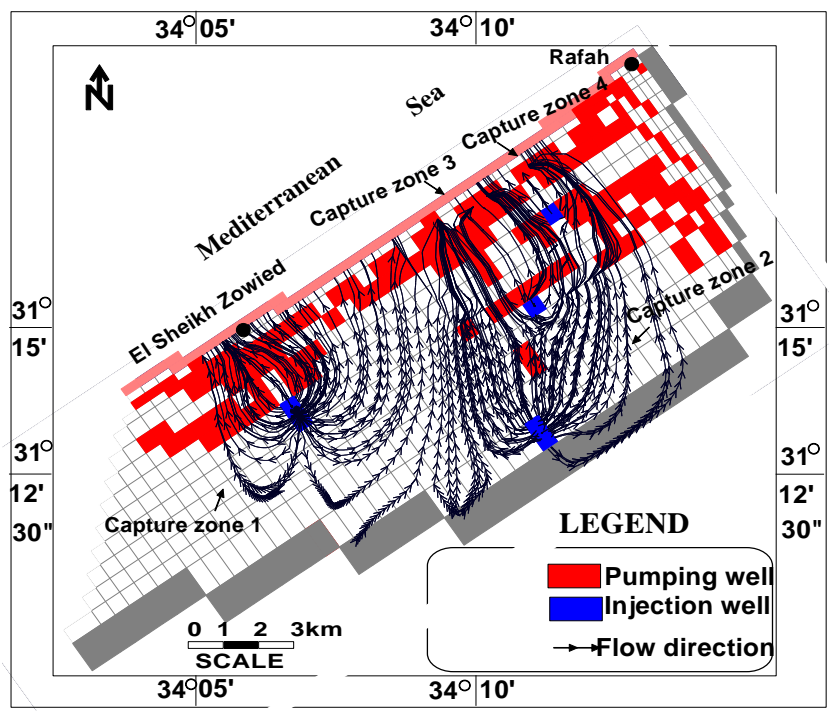

Fig. 14: Different capture zones for the quaternary aquifer in El Sheikh Zowied - Rafah Area, North Sinai, Egypt. (First Scenario)

At capture zone (4) (at Rafah area) refers to an expected decrease in the concentration of salts plume from $1.800 \mathrm{~kg} / \mathrm{m}^{3}$ to $0.380 \mathrm{~kg} / \mathrm{m}^{3}$ associated with increase in water level up to $0.48 \mathrm{~m}$. The groundwater cleanup time is one year of injection, where desorption process took place. The remaining salts plume (residual) is $21 \%$ from the actual concentration. From the above mentioned results, it can be concluded that the average expected remaining salts plume will be $51.3 \%$ in the studied area. This ratio is good in modeling simulation, where no treatment station is applied. But it can be lowered in the field to reach $25 \%$ of the actual concentration, where the treatment station for removal the salts plume is present. During the simulation, small amounts of salt masses vary from 0.08 $\mathrm{kg} / \mathrm{m}^{3}$ to $0.300 \mathrm{~kg} / \mathrm{m}^{3}$ are retained near the injection wells. This represent the simulated salts plume that fails to represent slow and anomalous spreading at low concentration.

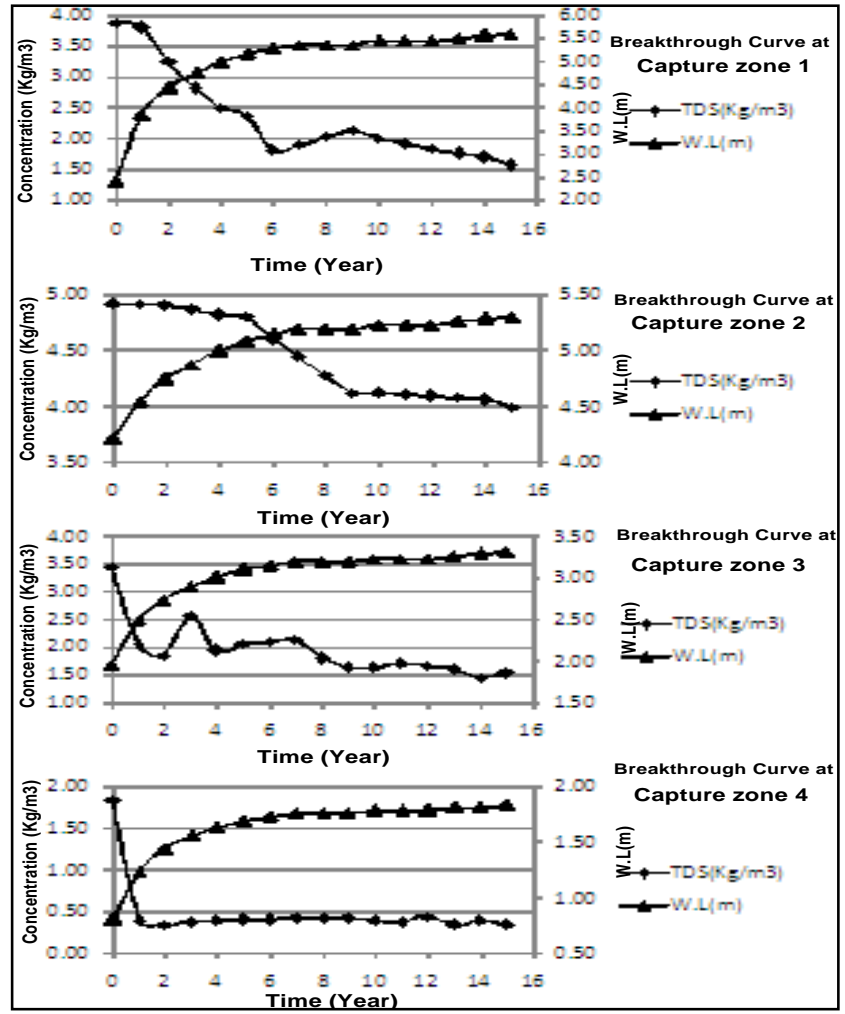

Fig. 15: Breakthrough curves and G.W levels plot at each capture zone for the quaternary aquifer in El Sheikh Zowied - Rafah Area, North Sinai, Egypt. (First Scenario)

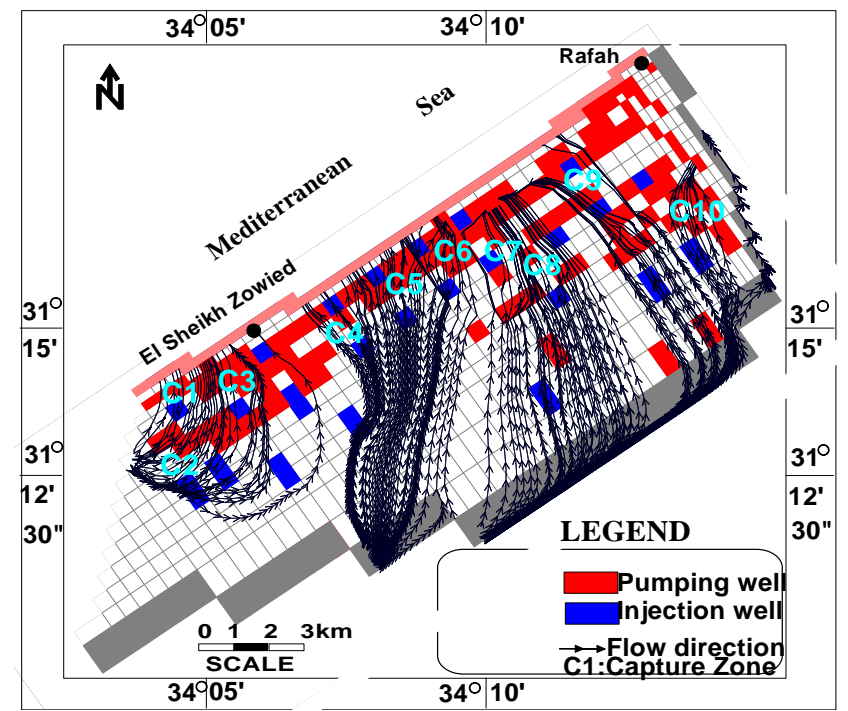

Fig. 16: Different capture zones for the quaternary aquifer in $\mathrm{El}$ Sheikh Zowied - Rafah Area, North Sinai, Egypt. (Second Scenario) 
The second scenario is applied by introducing 29 injection wells in the studied area with injection rate of $500 \mathrm{~m}^{3} /$ day per each well. The injection wells are distributed in the studied area according to different injection and pumping well patterns as mentioned above with constant concentration of $0.05 \mathrm{~kg} / \mathrm{m}^{3}$ for each well (Fig. 16). The model is running daily with 12 stress period of 30 day per each and 30 days time step with one transport step size for each stress period. The model is running in the transient time for 10 years. All pumping wells in the studied area were operated regularly during the simulation. The result of model simulation detects ten capture zones in the studied area (Fig. 16).

Three capture zones are delineated at El-Sheikh Zowied area (C1, C2 and C3). Four capture zones are delineated in the area between El-Shkeikh Zowied and Rafah area (C4, C5, C6 and C7). Three capture zones are detected at Rafah area (C8, C9 and C10). Breakthrough curves and groundwater plots are delineated at each capture zone. From such curves and plots, the following are deduced (Fig. 17):

At capture zone $(\mathrm{C} 1)$, the result of simulation refers to an expected decrease in the concentration of salts plume from $3.000 \mathrm{~kg} / \mathrm{m}^{3}$ to $1.270 \mathrm{~kg} / \mathrm{m}^{3}$. associated with increase in water level up to $0.68 \mathrm{~m}$. The groundwater cleanup time will be three years of injection, where desorption process took place. The remaining salts plume (residual) will be $42 \%$ from the actual.

At capture zone (C2), the result of simulation refers to an expected decrease in the concentration of salts plume from $4.700 \mathrm{~kg} / \mathrm{m}^{3}$ to $3.900 \mathrm{~kg} / \mathrm{m}^{3}$ associated with increase in water level up to $0.64 \mathrm{~m}$. The groundwater cleanup time will be four years of injection, where desorption process took place. The remaining salts plume (residual) will be $83 \%$ of the actual.

At capture zone (C3), the result of simulation refers to an expected decrease in the concentration of salts plume from $3.450 \mathrm{~kg} / \mathrm{m}^{3}$ to $2.280 \mathrm{~kg} / \mathrm{m}^{3}$ associated with increase in water level up to $1.25 \mathrm{~m}$. The groundwater cleanup time will be eight years of injection, where desorption took place. The remaining salts plume (residual) will be $66 \%$ of the actual.

Thus, the average expected remaining salts plume will be $63.7 \%$ at El-Skeikh Zowied area.

At capture zone (C4), the result of simulation refers to an expected decrease in the concentration of salts plume from $3.300 \mathrm{~kg} / \mathrm{m}^{3}$ to $1.260 \mathrm{~kg} / \mathrm{m}^{3}$ associated with increase in water level up to $1.26 \mathrm{~m}$. The groundwater cleanup time will be eight years of injection, where desorption took place.

The remaining salts plume (residual) will be $38 \%$ of the actual.

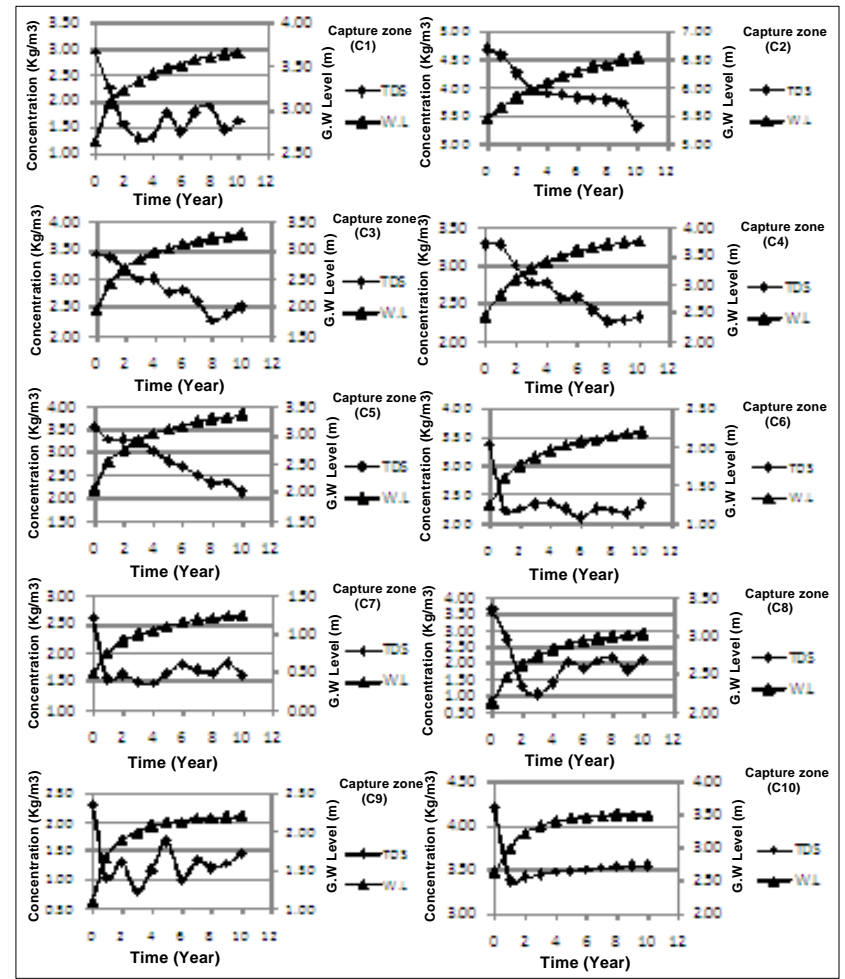

Fig. 17: Breakthrough curves and G.W levels plot at each capture zone for the quaternary aquifer in El Sheikh Zowied - Rafah Area, North Sinai, Egypt. (Second Scenario)

At capture zone (C5), the result of simulation refers to an expected decrease in the concentration of salts plume from $3.600 \mathrm{~kg} / \mathrm{m}^{3}$ to $2.300 \mathrm{~kg} / \mathrm{m}^{3}$ associated with increase in water level up to $1.22 \mathrm{~m}$. The groundwater cleanup time will be eight years of injection, where desorption took place. The remaining salts plume (residual) will be $64 \%$ of the actual.

At capture zone (C6), the result of simulation refers to an expected decrease in the concentration of salts plume from $3.400 \mathrm{~kg} / \mathrm{m}^{3}$ to $2.230 \mathrm{~kg} / \mathrm{m}^{3}$ associated with increase in water level up to $0.34 \mathrm{~m}$. The groundwater cleanup time will be one years of injection, where desorption process took place. The remaining salts plume (residual) will be $66 \%$ from the actual.

At capture zone (C7), the result of simulation refers to an expected decrease in the concentration of salts plume from $2.600 \mathrm{~kg} / \mathrm{m}^{3}$ to $1.400 \mathrm{~kg} / \mathrm{m}^{3}$ associated with increase in water level up to $0.57 \mathrm{~m}$. The groundwater cleanup time will be four years of injection, where desorption took place. The remaining salts plume (residual) will be $54 \%$ of the actual.

Thus the average expected remaining salts plume will be $55.5 \%$ in the area between El-Sheikh Zowied and Rafah.

At capture zone (C8), the result of simulation refers to an expected decrease in the concentration of salts plume from $3.600 \mathrm{~kg} / \mathrm{m}^{3}$ to $1.000 \mathrm{~kg} / \mathrm{m}^{3}$ associated with increase in water level up to $0.62 \mathrm{~m}$. The groundwater cleanup time will be three years of injection, where desorption took place. 
The remaining salts plume (residual) will be $28 \%$ of the actual.

At capture zone (C9), the result of simulation indicates an expected decrease in the concentration of salts plume from $3.350 \mathrm{~kg} / \mathrm{m}^{3}$ to $1.000 \mathrm{~kg} / \mathrm{m}^{3}$ associated with increase in water level up to $0.56 \mathrm{~m}$. The groundwater cleanup time will be one year of injection, where desorption took place. The remaining salts plume (residual) will be $30 \%$ of the actual.

At capture zone $(\mathrm{C} 10)$, the result of simulation refers to an expected decrease in the concentration of salts plume from $4.200 \mathrm{~kg} / \mathrm{m}^{3}$ to $3.300 \mathrm{~kg} / \mathrm{m}^{3}$ associated with increase in water level up to $0.37 \mathrm{~m}$. The groundwater cleanup time will be one year of injection, where desorption took place. The remaining salts plume (residual) will be $79 \%$ of the actual.

Thus the average expected remaining salts plume will be $45.7 \%$ at Rafah area.

The average expected remaining salts plume will be 55 $\%$ in the studied area. During the simulation, large and small amount of salts mass varies from $0.200 \mathrm{~kg} / \mathrm{m}^{3}$ to $1.500 \mathrm{~kg} / \mathrm{m}^{3}$ are retained near the injection wells. This represent that the simulated salts plume fails to represent rapid and slow and anomalous spreading at low concentration.

\section{CONCULSION}

The Quaternary aquifer in the studied area represents a complex system of groundwater. It consists of three water bearing rock units, lies under unconfined, semiconfined and confined conditions. They are connected hydraulically and form one hydrogeological aquifer system. Detailed description of applied models in the previous studies are presented, which are; hydraulic flow model ${ }^{[2]}$, salts transport model ${ }^{[4]}$ and hydrodynamic salts dispersivity model ${ }^{[5]}$. The current model is the hydrodynamic isolation system model. It is applied in the present study depending on the application of the previous three models. The current model is represented by network of irregular and regular cells of the same dimensions in the hydraulic flow model. Such model cover the area of 175.625 kilometer and discrete of 659 cells. The average grid Peclet number of the current model is 6.5. This Peclet number is acceptable to avoid numerical dispersion. The time required to achieve the cleanup standard of groundwater under various remedial alternatives is obtained by estimation of time required for one pore volume of clean water to be flushed through the area and multiplying this by the required number of pore volumes. The average retardation factor in the studied reaches 2.51 , where the dispersion is mostly common in the studied area. The mechanism of chemical processes that occurs in the Quaternary aquifer in the studied area reflects that salts plume, are removed from the water and immobilized in or on the solid matrix of the porous medium by electrostatic forces, which referred to sorption process.
The opposite process occurs, where the salts particles are detached from the solid matrix and reenter to dissolved phase which is referred to as desorption. The volume of water in pores for the Quaternary aquifer in the studied area varies from $0.1 \times 10^{6} \mathrm{~m}^{3}$ to $6 \times 10^{6} \mathrm{~m}^{3}$ for each cell of model grid. The higher volume is recorded in the southern areas, while the lower volume is recorded in the northern areas. The number of pore volume required for groundwater cleanup to specified level in the studied area varies from one pore volume in the northern area to six pore volumes for each cell of model grid in the southern area. The full replacement of single pore volume in all parts of the studied area in the Quaternary aquifer would require 660 days. The groundwater cleanup time of the Quaternary aquifer varies from less than 600 days in the northern area to about 3810 days in the southern area. The remedial technique such as hydrodynamic isolation system for groundwater cleanup need more time in the southern and middle areas than in the northern area. Cleanup time was found to be inversely related to the pumping rate. Hydrodynamic isolation system is molded for the Quaternary aquifer in the studied area. Two scenarios are concerned in the current model. In the first scenario, five injection wells are applied with different injection rate of pure water with concentration of $0.050 \mathrm{~kg} / \mathrm{m}^{3}$. The injection rates are 2000,5000 and $6000 \mathrm{~m}^{3} /$ day. The model is running daily for 15 years. All pumping well were operated regularly during the simulation. The result of simulation detects four capture zones in the studied area. Breakthrough curves and groundwater plots are adopted at each capture zone. They demonstrate the simulated changes of concentrations and water level over time clearly. Such curves and pots indicates an expected decrease in concentration of salts plume in the studied area at each capture zone from about $16 \%$ to about $79 \%$ of the actual concentration. The average expected remaining salts plume will be $51.3 \%$ in the studied area. The groundwater plots refer to an expected increase of water levels from about $0.48 \mathrm{~m}$ to about $2.87 \mathrm{~m}$. The groundwater cleanup time is expected to vary in the studied area from about one year to about nine years of injected pure water. In the second scenario, 29 injection wells introduced in the studied area with injection rate of pure water of $500 \mathrm{~m}^{3} /$ day per each well. The concentration of pure water is $0.050 \mathrm{~kg} / \mathrm{m}^{3}$. The model is running daily in the transient time for 10 years. All pumping wells were operated regularly during the simulation. The result of simulation detects ten capture zones in the studied area. Breakthrough curves and groundwater plots are delineated at each capture zone. Such curves and plots indicates an expected decrease in concentration of salts plume in the studied area from about $17 \%$ to $72 \%$ of the actual concentration at each capture zone. The average expected remaining salts will be $55 \%$ in the studied area. The groundwater plots refer to expected increase in water levels from about $0.34 \mathrm{~m}$ to about $1.26 \mathrm{~m}$ in the studied area at each capture zone. 
The groundwater cleanup time is expected to vary from about one year to about eight years of injected pure water.

The detected capture zones of the two scenarios refers to the following points:

1-The simulated salts plume appeared is expected to decreases more in the studied area than the actual.

2-The dissolved salts plume should move in the direction of groundwater flow.

3-Such remedial technique not be able to remove all terraces of salts plume

4-In existing of the treatment station in the field, the capture zone plume will be decreased in its concentration more and more than the a actual and the remaining salts plume will be lowered to reaches $25 \%$ as tested on the other area by Burgess ${ }^{15}$ and copyright in Bedient et. al. ${ }^{[11]}$.

5-The hydrodynamic isolation system can be applied in the northern and middle areas in the studied area, while the groundwater in the southern area has marine origin of solid porous matrix with highly saline groundwater. Thus, this part of the Quaternary aquifer should be excluded from the area targeted for further remediation. The hydrodynamic isolation system model can be applied in the coastal areas of the Mediterranean sea, the Red sea and in the Arab Gulf. It can be applied in the other coastal areas in the world and in the inland areas for the aquifers with higher salinity of groundwater.

\section{RECOMENDATION}

The obtained results of the current study give rise to the following recommendations:

1-The hydrodynamic isolation system technique should be applied by using the second scenario with increasing of injection rate to $1000 \mathrm{~m}^{3} /$ day for each injection well. 2-Some certain chemical solvents should be added to the injected water to remove the concentrated salts mass on the solid matrix.

\section{ACKNOWLEDGMENT}

Praise to GOD, lord of the worlds, by the grace of whom the implementation of this work was possible.

\section{References}

1) Fettig J.D., (1994). "Groundwater Pollution Primer", CE 4594, Soil and groundwater pollution, Civil Engineering Dept. Virginia Tech.

2) Arab center for studies and arid zones and dry land and Desert research center (ACSAD and DRC) (1998). "The Mathematical Model for El Sheikh Zowied-Rafah, North Sinai, Egypt", ACSAD, W.S./R123/ Damascus (in Arabic), $234 p$.

3) El Tablawi E.M.S. (1997). "Sea Water Intrusion in the Coastal Aquifer Between Rafah and Sheikh Zowied (North Sinai) and its impact on the surroun- ding environment", M.Sc. Thesis, Institute of Environmental Studies and Research, Ain Shams University, Egypt. 199p.

4) EL Tablawi E.M.S. (2009). "Study of the Groundwater Movement With Salt Water Intrusion Using the Mathematical Modeling in El Sheikh Zowied-Rafah, North Sinai", Journal of Geology, Assiut Univ., 38(I): 45- 61.

5) EL Tablawi E.M.S. (2010). "The Effect of Physical Processes on the Salts Transport in Sea water Intrusion areas (Case Study, El-Skeikh Zowied Rafah, North Sinai”, Egyptian Journal of Pure and Applied Sciences, Issn:2090-231 X, 48: 39-52.

6) Research Institute of Water Resources (RIWR), (1988). "Groundwater Management Study in ElArish - Rafaa Plain Area", Phase 1, Vol. II, Cairo, $166 \mathrm{p}$.

7) Chiang H.W. and Kinzelbach W. (1998). "Processing Modflow", 3D-Groundwater Modeling with PMWIN, a Simulation System for Modeling Groundwater Flow and Pollution, ISBN 3-54067744-S Springer - Verlag Berlin Heidelberg, New York.

8) Huyakorn P.S. and Pinder G.F. (1983). "Computational Method in Subsurface flow, Acadimic Press, 473p.

9) Zheng C. and Benett G.D., (2002). "Applied Contaminant Transport Modeling", Second Edition, John Wiley and Sons, Inc. New York, 621p.

10) EI Tablawi E.M.S. (2008). "Study of Water Quality Changes With Groundwater Movement Using Mathematical Modeling Technique, South of El-Nasr Canal, East of Cairo-Alexandria Desert Road, Egypt.", Ain Shams University, Journal of the Faculty of Education, Science Section, 32: 7- 47.

11) Bedient P.B., Rifai H.S., Newell C.J. (1994). "Groundwater Contamination Transport and Remediation", New Jersey, Prentice Hall, 541p.

12) Cherry J.A.W., Gillham and J.F. Barkker (1984). "Contaminant in Groundwater: Chemical Processes in Groundwater Contamination", National Academy Press, Washington, DC, 46-64.

13) Satkin. R.L. and Bedient P.B. (1988). "Effectiveness of Various Aquifer Restoration Schemes Under Variable Hydrogeologic Condition", Groundwater 26(4), 488-98.

14) Hazel C.P., (1975). "Groundwater Hydraulic", Lectures of Irrigation and Water Supply Commission, Queens Land to the Australian Water Resources Council's, Groundwater School, August.

15) Burgess K.S. (1993). "Flow and Transport modeling of Heterogeneous Field Site Contaminated With Dense Chlorinated Solvent Waste", Thesis Submitted in Partial Fulfillment of the Required for The Degree Master of Science, Rice University, Houston, TX. 